\title{
Developing Intercultural Competence among Moroccan EFL students: Focus on Raising their Cross-cultural Awareness
}

\author{
Driss Benattabou \\ Moulay Ismail University, Morocco \\ d.benattabou@gmail.com \\ DOI: http://doi.org/10.36892/ijlls.v2i3.339
}

\begin{tabular}{|c|c|}
\hline Received: & Abstract \\
\hline $26 / 06 / 2020$ & $\begin{array}{l}\text { The goal of this paper is to consider alternative ways to incorporate an } \\
\text { intercultural communication course as an integral part of the curriculum }\end{array}$ \\
\hline $\begin{array}{l}\text { Accepted: } \\
\text { 06/09/2020 }\end{array}$ & $\begin{array}{l}\text { designed for Moroccan learners of EFL. Some aspects of what comes to be } \\
\text { dubbed as 'deep culture' should find room in the contents of the EFL course } \\
\text { so as to alert Moroccan learners about the potential intercultural barriers }\end{array}$ \\
\hline $\begin{array}{l}\text { Keywords: } \\
\text { EFL learners; } \\
\text { intercultural } \\
\text { communication; } \\
\text { communication } \\
\text { breakdown; deep } \\
\text { culture; cross- } \\
\text { cultural } \\
\text { misunderstanding. }\end{array}$ & $\begin{array}{l}\text { they are far more likely to face. It is proposed that for an effective } \\
\text { intercultural communication to take place, the English course should help } \\
\text { foreign language learners explicitly understand what target linguistic forms } \\
\text { might be and how their meanings may differ across cultures. The analysis of } \\
\text { some instances of intercultural misunderstandings may surely give more } \\
\text { credence to the vital importance of implementing a multicultural approach to } \\
\text { education. This paper offers some teaching strategies to assist Moroccan } \\
\text { learners of EFL overcome these intercultural barriers. }\end{array}$ \\
\hline
\end{tabular}

1. INTRODUCTION

This paper is an attempt to touch upon some of the potential areas that may cause cultural misunderstandings between interlocutors from diverse cultural backgrounds. Moroccan learners of EFL, I believe, must be on the alert against any misconceptions that are prone to arise from such cross-cultural encounters. Unless they are made cognizant of such cultural mismatches, students will surely continue to make a lot of unintentional offences both as encoders and/or decoders.

Our teaching experience with students demonstrates that their ability to use English for multiple communicative purposes is far from being properly settled, and there is a need to exert more effort to develop their intercultural competence. Language learning, according to Bentahila and Davies (1997), should be more than the learning of syntax, vocabulary and pronunciation. In essence, it should also incorporate the ability to interact and communicate with people from diverse cultural backgrounds. Language learners should; therefore, be assisted to understand that conversational routines may substantially differ from one language/culture to another, and what can be perceived as normal, desirable and appropriate in one culture, may be considered as undesirable, inappropriate and utterly unacceptable in another.

To ensure success in inter-cultural communication it is required from the learners of EFL to hone not only their ability to use well-formulated sentences, but entails also their capability 
to produce and understand a total range of cultural conventions and norms in issuing a number of communicative speech acts characteristic of the target language.

The paper is divided into four major sections. The first section presents a theoretical background discussing a plethora of arguments pertaining to such areas as communicative competence, the role of culture in language teaching and the building up of intercultural communication. The second section delineates and explains some examples of intercultural communication barriers Moroccan learners of EFL are prone to experience. A general discussion of the issues outlined in this paper is presented in section four. The final section offers some teaching practices that may help language learners compensate for communication breakdown.

\section{Theoretical issues}

In compliance with the recently adopted educational reform, a number of university institutions all over Morocco have tried to make some modifications at the level of their syllabi. To reflect such a change, new courses have been incorporated within these curriculums like Business English, Computer Skills, and English for Tourism to live up to the new requirements of the job market. There is also room for such courses as Introduction to Culture and Cultural Studies. Scant attention however, has been made to consider what Ouakrim (1992) and Sadiqi (1992) refer to as 'deep' culture studies.

Every language is unique and tends to differ substantially from other languages not only in terms of linguistic rules but also in terms of cultural conventions and norms (Wierzbicka, 2003; Byram, 1997; Alred et al., 2003; Davies, 1992; Bentahila and Davies, 1997, among others). Drawing on such a premise, a number of scholars and educationalists argue for the crucial importance of integrating the teaching of 'deep culture' in language education to help students foster their intercultural competence. This knowledge, according to a number of scholars, will assist them to avoid the socio-pragmatic barriers that may arise from any potential misunderstanding during intercultural communication ( Kerouad, 2001; Benattabou, 2011). Cross-cultural research in the area of language learning and teaching demonstrates the existence of significant contrasts between the learners' native language and the target language pointing towards more socio-pragmatic problems.

Relying on the insights from prior sociolinguistic research, it has been argued that foreign language learners should be taught intercultural communicative competence in order to facilitate their endeavour to communicate efficiently and to shun cross-cultural misunderstanding. Their argument rests on the premise that despite a learner's familiarity and efficiency in manipulating the target language, without conscious awareness of the cultural conventions and norms of the target language and culture, a wide range of intercultural failures might emerge. 
There is a danger that foreign language learners may inadvertently offend others without meaning to due to the cultural dissimilarities characterizing both the learners' native language and the target language. There is a need to empower their linguistic and socio-pragmatic ability to assist them successfully ensure communication across languages as well as raise their consciousness of the intercultural misconceptions emerging from any differences in conventions, beliefs and values (Wierzbicka, 1985; Davies, 1992; Mouaid, 1992; Ouakrime, 1992; Sadiqi, 1992; Bentahila and Davies, 1997; Byram, 1997; Alred et al., 2003).

Accordingly, Fitzgerald (2003) researched the role of culture in foreign language teaching and recommends the incorporation of intercultural communication as an integral part of the ELT syllabus. Alfred and Byram (2002) elaborate more on the issue contending that:

In any society which expects its education system to prepare people for living in an internationalised culture and globalised economy, and also for the interaction between people of different cultures within and across national boundaries, the process of tertiary socialisation and the acquisition of intercultural competence are clearly desirable. (Alfred and Byram, 2002, p. 351)

The arguments of this study are that to communicate appropriately in English with target language speakers, Moroccan students of EFL need to be supported to promote their intercultural communicative competence comprising not only the rules of grammar but also the conventions and norms of speaking as well (Ouakrime, 1992; Bentahila and Davies, 1997; Byram, 1997; Wierzbicka, 2003; Alre et al., 2003; Fitzgerald, 2003; Benattabou, 2011).

To hone students' proficiency in the target language, some cultural aspects pertaining to such subtle cultural issues as beliefs, attitudes, values and world views must find room in the ELT programs. The paper sets out to address the contention that without such an awareness of the cultural discrepancies regarding the learners' native language/culture and those of the corresponding target language/culture, students will only be induced to undergo more psychological frustrations and embarrassments educationalists have often striven to eradicate.

\section{Some areas of cross-cultural misunderstanding}

Research on cross-cultural communication, particularly with respect to the Moroccan context ( Bentahila, 1992; Davies, 1992; Mouaid, 1992; Ouakrime, 1992; Sadiqi, 1992; Bentahila and Davies, 1997; Kerouad, 2001; Benattabou, 2011) offers more insightful examples of the linguistic differences between Moroccan Arabic and English in the performance of a number of speech acts. The Moroccan students' imperfect command of using the appropriate linguistic routines and the politeness formulas to issue such conversational functions like thanking, requesting, apologizing, to name but only a few, is perhaps the source which triggers most of the failures in inter-cultural communication. 
To demonstrate the potential for cross-cultural misunderstanding as a result of the differences in the linguistic and socio-pragmatic conventions characteristic of both the learners' native language and those of the target language, let us consider some linguistic instances used by Moroccan learners of EFL.

The problems that students might potentially face in this connection emanate from their being stuck to the linguistic devices pertaining to Moroccan Arabic and fail to recognize that languages do vary enormously in the expression of a multitude of communicative acts. In many classroom activities, for instance, EFL teachers seem to be somehow frustrated to hear such expressions Moroccan students are bound to use as a request:

- Speak a bit loudly/slowly, please!

- $\quad$ Teacher, repeat the last example!

- $\quad$ I want you to correct for me an essay.

- $\quad$ I want to go out.

- $\quad$ Give me my exam paper, please!

It is very unfortunate that Moroccan students do not seem to possess the linguistic devices to make a request, and seem to be unaware that the power relationship between a teacher and a student, for example, conventionally requires from the latter to be more formal and to be tactfully polite. While these sentences are structurally well-formulated and communicate perfectly the intended meaning of the students, they are pragmatically inappropriate as the use of the imperative form is commonly perceived as being offensive and impolite to English native speakers. Moroccan learners issuing these utterances are by no means impolite and rude, but only pragmatically incompetent lacking the appropriate communicative formulas required in these contexts. What follows from this is that teachers need to enrich their students' linguistic repertoire and have them realize some other strategies to issue the most conventionalized formulas for making a request in English as:

- Could you speak a bit loudly/slowly please?

- If I may interrupt, there is an idea I'm not sure about, would you mind going over that again please?

- Excuse me, could you reiterate the last idea?

- Sorry, I didn't quite follow you, could you please explain that again?

- Could I have my exam paper, please?

Other examples Moroccan students are prone to use in class, and that is found to be rather unusual among English native speakers is when they would like to make a suggestion. For example, a student would say:

- I want to give an oral presentation next week.

- Can we postpone the correction of the exercise?

What characterizes these suggestions is that they are blunt and sound a bit forthright, impolite, and rude. What a Moroccan student/interlocutor must be aware of here is that the 
conventional use of a suggestion in English should be phrased in the form of a negative question which would perhaps sound more tactful, polite and even pleasant to the English native listener/interactant as in:

- Wouldn't be possible for me to deliver my oral presentation next week?

- Wouldn't be better to postpone the correction of the exercise?

Similarly, in socializing as in the case of "phatic Communion", it is quite common among British people to talk about the weather and to use tag questions as a conversational device to break the ice and invite the addressee for 'a small talk':

A. Lovely/beautiful day, isn't it?

An utterance like this one calls for a quick response. Not responding to this social starter might be taken as a socio-pragmatic failure. Students must be taught that in such specific situations, they are not conventionally expected to keep silent or just say yes. Rather, the cultural recommendation is that they are supposed to express agreement by repeating the same formula but in a different way:

B. Yes, wonderful!

Absence of any response from the part of a Moroccan student sitting nearby an old lady who used the first expression, say in Marrakech for example, might perhaps be a source of embarrassment for both of them. The danger of this state of affairs is that cultural misconceptions may be prevalent on both sides. The English native tourist (speaker) may wrongly think of the Moroccan as being unsociable, hostile, or even uncivilized, while the Moroccan interlocutor may perceive the English speaking person as an intruder and therefore untrustworthy. This is in fact a serious cultural gap students must be aware of. Such an intercultural misunderstanding may be detrimental and may surely be not to the benefit of the participants involved.

The learner of English as a foreign language must be knowledgeable of the conversational routines as dictated by the social dimensions of 'phatic communion', the conventional aspects of which require from him/her sociable talk to show interest in the topic under discussion and to employ the polite forms as imposed by the situation.

Other more interesting examples of communication breakdown across cultures have been pinpointed even at the level of English writing. Moroccan learners of EFL are reported to fail in issuing an appropriate form of a request in English where, unexpectedly, they mix it up with the feeling of "pleasure" and concoct the following:

"I am happy to apply for you once again about a great translation or comparative literature..."

"I am very pleased to ask for your help and guidance"(Bentahila, 1992, p. 64).

One is reasonably led to hypothesize with Bentahila (1992) that if such expressions were written to English native speakers, students would perhaps be perceived as being communicatively incompetent, giving a very bad impression about them, which may possibly work at their disadvantage either as students or future employees in a company. 
These students were also reported to be unsuccessful in trying to provide the right formulas to express an apology. There is a general tendency among Moroccan students to deny responsibility for failing to accomplish their tasks in due time, and to throw the blame upon other external factors:

"The late submission of my work is not due to any negligence on my part, but it is due to unfavorable and unexpected circumstances"

"The late submission of my work...........was not out of carelessness, it was against my own will" (Bentahila, 1992).

Most students were observed to display themselves as being unable to act against the will of fate: "against my will", "beyond my will" and "out of my will" (Bentahila, 1992).

Such an inappropriate pragmatic transfer could perhaps be traced back to these daily conversational formulas in Moroccan Arabic depicting Moroccans as victims of extraneous factors:

- / mfa Slija tran/, literally 'the train has left me'

Another similar but funnier example is:

- / ḍrebni lhit /, literally 'the wall hit me'

In English-speaking cultures however, this pattern of thinking prevalent in the Moroccan mindset is thought of as being inappropriate - a bad workman always blames his tools, as the English proverb reads- and any attempt to find an extraneous factor as an excuse for one's faults is culturally resented. A translation of the two Moroccan daily expressions may sound something like: 'I missed the train', and 'I bumped into a wall', respectively, in which case the speaker, through the use of the passive voice where the personal pronoun has been deleted, denies responsibility in the Arabic version of the expression.

The same pattern can be found in French as in:

"J'ai raté le train" (I missed the train in English)

Both in the English and French speaking cultures, it is much more common among people not to disclaim responsibility. They are instead more liable to admit being committed through the linguistic device of the personal pronoun 'I' in English, or 'Je', in French, and the use of the active voice rather than the passive one as in the Moroccan Arabic version as explained earlier.

A cross-cultural approach to compare and contrast between the learner's native language/culture with the target language/culture is prone to provide substantial educational support to foreign language teachers and learners, enhancing in this connection their attempt to understand and come into grips with the different sources of intercultural misunderstandings. 
It is perhaps unwise to leave students in a state of doubt. Instead, they must be taught in role plays how to behave courteously and how to avoid appearing unfriendly and unsociable. Social beliefs and cultural norms differ considerably from one culture to another, and it is true that EFL students must be warned against any tactless or impolite messages they may unintentionally communicate.

Further potential mistakes may emerge from the foreign language learner's inadequate awareness of the politeness strategies that might be used to express thanks in face-to-face interactions. There is a general tendency among English speaking people to thank their interlocutors even for the slightest services they may offer. A Moroccan husband, for instance, is not culturally expected to thank his wife for bringing a cup of tea or water; otherwise, he might sound as being ironical and perhaps meaning the opposite. In the English speaking community; however, wives do conventionally expect an expression of thanks in this situation (Davies, 1992). This is in fact another very serious cultural gap students should be explicitly made aware of.

There are indeed vast cultural discrepancies in what is considered polite and what is not. Conversational strategies to express courteousness in Moroccan Arabic may conflict those used in English.

What follows from this is that cross-cultural communication problems may also arise from the learner's unsuccessfulness to discern the appropriate routine formulas to resort to in very specific situations. EFL learners' unawareness of the right discursive formulas that should be used as dictated by the context may, unfortunately, be interpreted as impolite or even worse as eccentric. The threats that these intercultural differences may engender are aptly accounted for in Davies' (1992) contention that "bad impressions can (...) be made either by not using a routine enough or by overusing it when it is not felt to be required" (Davies, 1992, p.74).

Similarly, when Moroccan students of EFL intend to make an apology for not having done an exercise they are expected to undertake, or for having dropped unintentionally handouts on the floor, they have often been found to lack the appropriate tools to make an apology, and are more likely to express their regretfulness. The only utterance they are familiar with in this context is the mere use of the two words expression: 'Sorry, teacher!'

What is conventionally expected from a student to say in these contexts, according to the socio-cultural norms of English, is to express one's sorrow for the inconvenience and promise to take urgent measures to help solve the problem as in:

'I'm very /terribly sorry, Sir, for the inconvenience, I'll look into the matter straightaway'.

'Awfully sorry, Sir. I will take up the matter immediately'.

Rather than responding merely by saying sorry, students must be taught to say sorry, express regret for being inappropriate and promise not to make the same mistake once again (Mouaid,1992). 
Accordingly, students must be helped to recognize that the grammatical structures they are likely to produce either in speaking or in writing must in no way be looked at in abstraction from the social context in which they are expected to operate. Rather, students should be made aware of the multiple communicative aspects evidently interconnected with them, and of the social constraints shaping the way such social routines are to be expressed.

Hymes (1971) and Ervin-Tripp (1973), among others, reason in this connection that, along the structural rules that form the basics for a speaker's use of language, there are other more conventionally interrelated and essential strategies "reflecting who the speaker is addressing, where he is, what the social event may be, the topic of discussion and the social relations he communicates by speaking" (Ervin-Tripp, 1973, p.286).

\section{TEACHING IMPLICATIONS}

Educational specialists interested in the study of the importance of incorporating elements of the target culture as a fundamental part of the EFL curriculum suggest a plethora of teaching strategies to help foment foreign language learners' awareness to avoid cross-cultural miscomprehension and misunderstanding. One is reasonably led to contend in this respect that it would not be enough perhaps to acquaint Moroccan learners merely with aspects pertaining to 'formal culture', but a full understanding of what comes to be called 'deep culture' is also essential and constitutes a fundamental part of intercultural communication competence.

To place students in the right track to engage successfully and effectively in any crosscultural interaction, and to foster their communicative intercultural competence, a number of instructional strategies have been proposed to serve this purpose, three of which, in my view, seem to be of far-reaching teaching and learning implications. The critical incident exercise, role playing and the exploitation of audio-visual media tools are three cultural techniques expected to sensitize students and familiarize them with basic issues pertaining to the target language and its culture. These three techniques are reported to bring about very promising educational gains for EFL learners.

\subsection{The critical incident exercise}

One of the widely recognized and recommended techniques to teach the target language and culture is the critical incident exercise (Cushner, 1989; Mouaid, 1992; Oxford, 1997; Kerouad, 2001; Apedaile and Schill, 2008; Snow, 2015; Tran et al., 2019).

Perceiving the vital role critical incidents may play in teaching culture, and raising foreign language learners' consciousness about the problems of intercultural communication, Apedaile and Schill (2008) define them as:

"brief descriptions of situations in which a misunderstanding, problem, or conflict arises as a result of the cultural differences of the interacting parties, or a problem of cross-cultural adaptation and communication. Each incident gives only enough information to set 
the stage and then describes what happened and possibly manifests the feelings and reactions of the people involved" (p. 6).

The teacher provides students with items/triggers of the target culture that may cause a serious communication breakdown. The topics presented for discussion should revolve around such cultural themes as beliefs, attitudes, norms, stereotypes, rules of formality, among others. After reading or listening to the incident, students are assigned multiple-choice questions to tick the correct answer. Students are also invited to pin down the source of the failure and are encouraged to suggest ways to rectify the problem. Through classroom discussion, the teacher provides feedback and reorients learners to the most appropriate interpretation. Students need also to be sensitized and incited to know that learning some aspects of the foreign culture will grant them an added value, and will be seen as a source of cultural enrichment for them.

An instance of such misunderstanding in intercultural dialogue between a Chinese girl and her American friend has been extracted from Liton (2016, p. 3):

Hey, puppy, you look lovely today!

What? Am I your pet dog?

Oh, I mean baby, please.

Because of the different cultural meanings associated with the use of the word 'puppy' in both the Chinese culture and the American culture, the girl feels being utterly offended. While in the American lifestyle the word 'puppy' stands for a pet name and carries an expression of endearment in complete congruence with the intentions of the American friend, in the Chinese culture, the word carries negative and derogatory overtones. This is indeed a very serious cultural barrier that may be conducive to more frustrating and embarrassing social interactions.

Apedaile and Schill (2008) propose a host of critical incidents that could be exploited for classroom purposes. Though the following critical incidents have been designed by Canadian educationalists to instruct newcomers to Canada, they can be implemented in other educational settings to promote intercultural communicative competence. Below are two examples of these critical incidents borrowed from Apedaile and Schill (2008):

1. Len teaches the evening TOEFL (...), class. One day there was a conflict between

a student who wanted to do more listening practice in class and a student who wanted to focus only on grammar. The next day, one of the two students came to Len's office to talk to him about the class. She told him that she thought they had studied enough grammar and that they needed more listening practice. She assured him that she was not trying to tell him what to teach. A week later she invited Len to come to her home so that she could show him something. He did not go. Then she sent him an e-mail, thanking him for his teaching and complimenting him on his looks. This made him very uncomfortable, so he made a conscious attempt to 
avoid her outside of class (p. 56).

2. There is a student in my class who is always late. That is not the only problem. When I ask him a question, he goes on and on and on and makes the rest of the class wait and wait. I want to tell him to get to the point. Finally, I have to cut him off because he loses track of the time he is taking up in class on his issue. I tell him that if he wants to continue talking about it, he'll have to do it on his coffee break. He doesn't understand our concept of time. We are on a strict schedule and things have to be done by a certain time; as well, things are scheduled to take a certain amount of time. I don't like it either-I hate it (p. 57).

\subsection{The effectiveness of role play}

This is another highly-instructive technique developed and recommended to serve the same purpose of drawing the attention of EFL learners to a number of cultural themes which may stand as a stumbling block against the accomplishment of any communication act. Role play is defined as a drama-like classroom activity during which EFL learners are induced to act out an array of role-play scenarios akin to real life contexts. With the help of teachers, learners are encouraged to perform and rehearse different types of conversational routines. They play the role of culturally divergent interlocutors interacting in different social encounters and performing different speech acts (Richards, 1985; Mouaid, 1992; Kerouad, 2001).

The topics the role plays are displaying should revolve around some cultural aspects suspected to trigger intercultural communication problems. Through role plays, students are incited to act out dialogues developing one single cultural theme at a time.

Damnet (2008) considers role play as "one unique set of experimental teaching techniques, which assists the English as a foreign language learners to deal with handling human situations and uncertainty as it puts the EFL students in a condition, which exploits the same type of constraints, motivations, and pressures that exist in real life" (p. 67).

\subsection{The use of audio visual media tools}

Audio visual media tools including videotaped materials, films, and filmstrips are commonly recommended as more instructional tools which can present foreign language learners with an opportunity to see and have a feel for the target language and culture (Hurley, 1992; Peterson and Coltrane, 2003; Damnet, 2008). According to Hurley (1992) "the inclusion of target-culture videotaped material", and films and filmstrips are no exception, "of different types of interactions can help enhance awareness of relevant norms and resources, whether verbal, prosodic, or non-verbal, for carrying out these interactions" (p. 274). 
Similarly, through films and videotaped materials, students' motivation will certainly be heightened as they will have an opportunity to be in direct contact with authentic language use, in an authentic social context, and with authentic target language speakers. Garies (1997) reminds us of the instructional utility of movies explaining that:

Feature films are among the most stimulating tools for language instruction of adolescent and adult learners. Most students enjoy watching movies and are interested in understanding the dialogues and cultural references. Combining language and visual support, films offer an ideal background for language acquisition as well as endless opportunities for pedagogically sound classroom activities (p. 20).

\section{GENERAL DISCUSSION}

An effective implementation of the 'critical incident' exercise along with role plays and the exploitation of audio visual media tools requires from the teacher to take a new role that of a 'cultural interpreter' (Apedaile \& Schill, 2008, Damnet, 2008; Ouakrime, 1992; Sadiqi, 1992) who may assist students to come into grips with the essence of the cultural issue in question, and increase their awareness of the potential risks that any cross-cultural encounter may engender. Foreign language teachers are expected to transcend the 'common' teaching responsibilities they are entrusted with. They may, for example, prepare classroom discussions presenting multiple critical incidents involving unintentional misunderstandings between two interlocutors of different cultural backgrounds, and help students spot the right communicative blunder, be it verbal or non-verbal. The same thing applies for the exploitation of classroom role plays and the implementation of audio visual media tools.

English language studies at the university level, according to Sadiqi (1992) and Ouakrim (1992), must endorse a pluralistic approach and a multicultural syllabus that would give an indepth knowledge of the target language and its community, foster a positive attitude, and instil in the learners a spirit of tolerance, cooperation and acceptance of the other.

Wiseman (2002) seems to capture the essence of the problem contending that intercultural communicative competence "involves the knowledge, motivation and skills to interact effectively and appropriately with members of different cultures" (p. 208).

One may argue at this stage that if cross-cultural studies must be incorporated within the English syllabus, then there is the further worry that Moroccan students may run the risk of experiencing a feeling of being either ethnocentric or culturally alienated. Such psychological orientations among students may surely be detrimental, and may hinder the successful accomplishment of any learning process.

It is not uncommon among second/foreign language learners to conceive of the norms and values of their own native language and culture as standard and uniform across cultures. Students are unavoidably prone to filter any information pertaining to the foreign language and culture from their cultural lenses assuming that their behaviour and values are universal, natural and even appropriate compared with those of other speech communities. 
Contrariwise, language learners may get a sense of cultural alienation looking at their local beliefs and cultural guidelines as inferior, underdeveloped, or even worse as primitive. This would represent a psychological barrier and a threat to their social identity.

Such bipolar orientations among language learners may develop certain hostility either towards the target language and its community, or towards their own local values and attitudes, thereby curtailing their chances to be good language learners.

According to Rubin (1981), foreign language learners must be encouraged to develop empathic and non-ethnocentric attitudes that would perhaps place them in an optimum position to be neither culturally alienated nor ethnocentric, and to see themselves and others as culturally distinct but on equal footing, being neither subordinate nor chauvinistic and dominant.

Being fully aware of the vital role of incorporating aspects of the target culture in EFL curriculum, Davitishvili, (2017) aptly contents that " developing critical cultural awareness enables one to learn and grow, to change and evolve, so as to meet the challenges of today's emerging global reality" (p. 555).

\section{CONCLUSION}

The implication that may crop up from such a discussion is that Moroccan learners of EFL must be fully acquainted with such cultural discrepancies, and surely other more subtle ones, so as to enhance their intercultural competence and to lessen from the likelihood of offending members of the target language community. Many cross-cultural miscomprehension and misunderstanding could perhaps be eliminated and avoided by simply drawing students' attention to them.

Many assumptions about other cultures are negative and stereotypical and there is a pressing need to assist students to dispel them so that an ethical interaction between members of diverse cultural backgrounds could be fostered and strengthened. Accordingly, EFL teachers are recommended to help language Lerners develop an empathic personality being able to act and behave as though one sees the world through the lenses of target language speakers.

\section{REFERENCES}

Alfred, G. and Byram, M (2002). "Becoming an Intercultural Mediator: A Longitudinal Study of Residence Abroad". Journal of Multilingual and Multicultural Development 23(5), 339352.

Alred, G., M. Byram and M. Fleming. (2003). 'Introduction', in G. Alred, M. Byram and M. Fleming (eds.), Intercultural Experience and Education (Clevedon: Multilingual Matters ): 1-13.

Apedaile, S. and Schill, L. (2008). Critical Incidents for InterculturalCommunication. Edmonton : NorQuest College.

Benattabou, Driss. (2011). "Communication studies and the Importance of Developing Cultural Awareness". Maknasat, N 21, Revue de la Faculté des Lettres et Sciences Humaines, Meknes. 
Bentahila, A. and Davies, A, (1997). "Culture and Language Use: A Problem for Foreign Language Teaching". In Dagmar Scheu Lottgen (ed.). Cultural studies in the classroom: Needs, problems and solutions. Murcia Universidad.

Byram, M. (1997). Teaching and Assessing Intercultural Communicative Competence, Clevedon, Multilingual Matters.

Cushner, K. (1989). Assessing the impact of a culture-general assimilator. International Journal of Intercultural Relations, 13(2), 125-146.

Damnet, A. (2008). Enhancing Acquisition of Intercultural Nonverbal Competence: Thai English as a Foreign Language Learners and the Use of Contemporary English Language Films. Online published PhD. Thesis. Victoria University Melbourne, Victoria, Australia.

Davies, E. (1992). "Routines and Realities: Some Sources of Misunderstanding in Croo-cultural Communication", In M. Dahbi, N. Tahiri \& T. Miller (Eds.), American studies in North African Universities: An interdisciplinary approach. Rabat. Imprimerie Eljadida.

Davitishvili, N. (2017). "CrossCultural Awareness and Teaching English as a Second Language in the Context of Globalization". Sino-US English Teaching, 14 (9): 549-558.

Ervin-Tripp, Susan. (1973). “Children's sociolinguistic competence and dialect diversity”. In: Anwar Dil; ed., Language acquisition and communicative choice: Essays by Susan M. Ervin-Tripp, 262-301. Stanford, CA: Stanford University Press.

FitzGerald, H. (2003). How Different are We? Spoken Discourse in Intercultural Communication. Clevedon: Multilingual Matters Ltd.002.

Garies, E. (1997). "Movies in the Language Classroom: Dealing with Problematic Content". TESOL Journal. 6/4: 20-23.

Hurley, D.S. (1992) "Issues in teaching pragmatics, prosody, and non-verbal communication". In: Applied Linguistics 13/3, 259-81.

Hymes, D. (1971). On Communicative Competence. In Pride, J. \& J. Holmes (eds.), Sociolinguistics, (pp. 269-293). London: Penguin.

Kerouad, S. (2001). An Evaluation of cultural competence and its development among Moroccan learners of English at the university. Unpublished doctoral dissertation. Faculty of Dhar Lmahraz. Fes.

Liton, H.A. (2016). “Adopting Intercultural Communication Issue in Teaching English". Lingua Cultura, 10(1).

Mouaid,F. (1992). "Two Techniques for Teaching Time and Distance in American Culture”. In M. Dahbi, N. Tahiri \& T. Miller (Eds.), American studies in North African Universities: An interdisciplinary approach. Rabat. Imprimerie Eljadida.

Ouakrime, M. (1992). “'Formal' and 'Deep' Culture for EFL students: Focus on the Learner”. In Dahbi, M., Tahiri, N. and Miller, T. (Eds.), American studies in North African universities. An interdisciplinary approach. Rabat. Imprimerie Eljadida.

Oxford, Rebecca L. (1997). "Cooperative learning, collaborative learning, and interaction: Three communicative strands in the language classroom". Modern Language Journal, 81, 443456. 
Peterson, E. and Coltrane, B. (2003) Culture in Second Language Teaching, Center for Applied Linguistics. www.cal.org/resources/Digest/digest_pdfs/0309peterson.pdf, Date of Access: 10.05.2020.

Richards, Jack. (1985) "Conversational competence through role play". RELC Journal 16:1

Rubin, J. ( 1981) “What the good language learner can teach us ?”. In Pride, J.B ( ed). Sociolinguistic Aspects of Language Learning and Language Teaching. Oxford .OUP.

Sadiqi, F. (1992). "A cross-cultural approach to the teaching and learning of English in Moroccan universities". A. In M. Dahbi, N. Tahiri \& T. Miller (Eds.), American studies in North African Universities: An interdisciplinary approach. Rabat. Imprimerie Eljadida.

Snow, D. (2015). "English teaching, intercultural competence, and critical incident exercises". Language \& Intercultural Communication, 15(2), 285-299.

Tran T. Q. T., Admiraal W. \& Saab N. (2019). "Effects of critical incident tasks on the intercultural competence of English non-majors". Intercultural Education, 30(6), 618-633.

Wierzbicka, A. (2003). Cross-cultural Pragmatics. The Semantics of Human Interaction. Second edition. Berlin and New York: Mouton de Gruyter.

Wiseman, R. L. (2002). 3Intercultural communication competence3. In W. B. Gudykunst, \& B. Mody (Eds.), Handbook of international and intercultural communication(2nd ed), (pp. 207-224). Thousand Oaks, CA: Sage.

\section{AUTHOR'S BIO}

Driss Benattabou holds a PhD. from Moulay Ismail University, Meknes, Morocco. His research interests include Applied Linguistics, Gender in Education, Critical Discourse Analysis and Visual semiotics. He teaches English at the Department of English, Faculty of Arts and Humanities, Meknes, Morocco. 